\title{
Everyday worry in adolescents with and without chronic pain: A diary study
}

$$
\text { Emma Fisher }{ }^{1} \mathrm{PhD} \text {, Edmund Keogh }{ }^{1} \mathrm{PhD} \text { and Christopher Eccleston }{ }^{1,2} \mathrm{PhD}
$$

Affiliations: ${ }^{1}$ Centre for Pain Research, University of Bath, UK; ${ }^{2}$ Department of Clinical and Health Psychology, Ghent University, Belgium

Address: ${ }^{1}$ Centre for Pain Research University of Bath, Claverton Down, Bath, BA2 7AY, UK.

Email:Dr Keogh: e.m.keogh@bath.ac.uk; Dr Eccleston: c.eccleston@bath.ac.uk

Corresponding author: Emma Fisher, Centre for Pain Research, University of Bath, Bath, BA2

7AY, United Kingdom. Phone: +441225 385434. Fax: +441225 386113. Email:

e.a.fisher@bath.ac.uk

Number of text pages: 11

Number of tables: 4

Number of figures: 0

Number of supplementary tables: 2

Word count: 1517

Funding: Emma Fisher was a PhD student funded by the University Research Studentship Graduate School Award, University of Bath.

Acknowledgments: We thank the participating schools and students. We also thank Joseph

Walsh Ph.D., Rhiannon Edwards, and Jessica Bartlett for their coding assistance.

Disclosure statement: Authors have no conflicts of interest 


\title{
Everyday worry in adolescents with and without chronic pain: A diary study
}

\begin{abstract}
Young people report frequent worry, but we know little about the extent, character, or consequence of worry in adolescence, or individual differences associated with worry.
\end{abstract} Adolescents with chronic pain are one population that are known to have high levels of anxiety, which is associated with higher levels of disability and depression, impairing function. In this study we report a diary study: adolescents $(N=60$; aged 16-18) recorded their worry over seven days. Our first aim was to describe the characteristics of adolescent worry and its consequences in a community sample. Our second aim was to compare the experience of girls to boys, and to compare the experience of those with and without chronic pain. Adolescents reported characteristics of each worry they had throughout the week, including content, frequency, strength, interference, emotion, and the strength of emotion associated with worry content. Adolescents reported the consequence for each content and the strength of the consequence. Worry content and consequences were categorised into four categories; health, relationship, personal competence, and other. Adolescents reported 675 unique episodes of worry over the seven-day period that were predominantly about personal competence. The strength of worry content was $(M=6.61, S D=1.27)$ and the strength associated with the worry consequence was $(M=5.59, S D=1.41)$. Worries were not reported as highly interfering $(M=4.14, S D=1.61)$. Contrary to predictions, there were no differences in worry characteristics between adolescents with and without chronic pain. To conclude, worry is a frequent occurrence in older adolescents and the characteristics of worry are discussed. Adolescents worry mostly about personal competence. Adolescents with and without chronic pain reported similar worry characteristics. Keywords: Adolescent; anxiety; chronic pain; worry. 


\section{Introduction}

Anxiety is common during childhood (Costello, Mustillo, Erkanli, Keeler, \& Angold, 2003) and is composed of cognitive, behavioural, and physiological responses to a perceived or anticipated threat (Warwick \& Salkovskis, 1990). Worry, an important feature of anxiety, can represent a developmental concern of perceived and anticipated threat during adolescence, and is higher in girls (Caes, Fisher, Clinch, Tobias, \& Eccleston, 2016; Szabo \& Lovibond, 2004). Increased worry has been associated with later poorer outcomes such as educational underachievement, increased alcohol consumption, and clinical disorders (Woodward \& Fergusson, 2001). Naturally occurring worry in adolescents tends to focus on social concerns (Weems \& Costa, 2005). For example, Vasey, Crnic, and Carter (1994) found that social, behavioural, and psychological worries increased from 5-14 years of age. However, there has been little examination of naturally occurring worries in older adolescence, which is a critical period of personal transitions and gaining autonomy (Laugesen, Dugas, \& Bukowski, 2003; Palermo, Valrie, \& Karlson, 2014), and a time when worry could flourish.

A secondary goal was to consider individual differences, and in particular compare the worry characteristics of those with and without chronic pain. This focus on pain is important because adolescence is a time when pain flourishes, particularly in girls (Perquin et al., 2000). Pain is surprisingly common; 25\% of children report recurrent pain (Perquin et al., 2000). Increased worry has been identified in older adolescents with chronic pain (Simons, Sieberg, \& Claar, 2012), which in turn is associated with higher disability and depression (Simons \& Kaczynski, 2012).

We aimed to describe the characteristics of worry in a community sample of older adolescents, and hypothesized that adolescent worry would be dominated by a concern for 
personal competence. (i.e. behavioural performance, social and personal evaluation (Vasey et al., 1994; Weems \& Costa, 2005). First, we predicted that girls will report more worries. Second, we predicted that adolescents with chronic pain will report more worries, particularly health worries, which will be stronger and more interfering (Eccleston \& Crombez, 2007).

\section{Methods}

\section{Participants}

Five schools consented to the study and distributed information sheets and consent forms to adolescents (16-18 years of age) and their parents to consider. Consent from the school, parent/guardian, and adolescent were obtained. Parents were also asked to identify their primary care physician in the case of an adverse event. The NHS Research Ethics Committee, and the University of Bath Psychology and Health Ethics boards approved this study.

\section{Self-Report Measures}

Adolescents reported their age, sex, ethnicity, and chronic pain status. Chronic pain status was identified by two questions; 1) Have you had any aches or pains that have lasted for a day or longer in the last month? (yes/no), 2) When did the pain start? (more/less than three months ago), (Von Korff, Ormel, Keefe, \& Dworkin, 1992). Adolescents who report that they have had aches or pain for a day or longer in the last month, and that started more than three months ago are known hereafter as Chronic Pain (CP).

\section{Worry diary}

A worry diary was designed for this study to capture normative worries of adolescents. Adolescents were asked to report the characteristics of their worries by completing the worry diary for seven days. Worries were defined in the diary as "...a thought that can come into your mind quite suddenly, and which is about something that has happened, or that you think might 
happen, and is unpleasant or makes you feel uncomfortable" (Borkovec, 1994, p. 7). Adolescents were asked to report the content of their worry, the strength and interference of each worry $(0-10$ scale; $0=$ not at all/not interfering; $10=$ very strong/very interfered), the emotion associated with each worry from a list of 15 emotions (e.g. angry, ashamed, confused, excited, frustrated, guilty, happy, helpless, hopeless, motivated, overwhelmed, sad, scared, silly, terrified), and the strength of the emotion ( $0-10$ scale; $0=$ not at all; $10=$ very strong). Adolescents also reported what they thought would happen if the worry came true (e.g. if they worried about failing a test, the consequence might be "I will get told off" [admonished]) and the strength of belief that the consequence would happen ( $0-10$ scale; $0=$ not at all; $10=$ very strong). No reminders were sent.

\section{Procedure}

Adolescents were given the demographic questionnaire and a worry diary. Once the seven-day period was over, adolescents were asked to return the questionnaires and worry diary in return for a $£ 5$ gift voucher. Adolescents were then debriefed.

\section{Data analysis}

\section{Worry identification and categorisation}

The worry content and consequences reported in diaries were collated and categorised using an iterative process. A coding system developed by Vasey and Borkovec (1992) and Vasey et al. (1994) was adapted to include four categories of worry relating to health, relationships, personal competence, and other. The coding framework was not validated before or during this study. Worry content and consequences were coded by three independent and Fleiss's Kappa was used to assess inter-rater reliability. For each categorisation, the majority opinion from the coders was assigned for each worry content and consequence coders and if all three coders disagreed then the worry was not assigned a category. For each adolescent, the 
quantity of worry content and consequences, the mean strength and interference of worry contents and the mean strength of worry consequences were calculated. Worry characteristics of adolescents; differences chronic pain status

Two MANOVAs investigated the differences between adolescents with and without chronic pain on 1) the quantity, mean strength, and mean interference of all worry contents and 2) the quantity and mean strength of all worry consequences. Due to the small number of males completing the study, it was not possible to conduct the planned analyses investigating the interactions between sex and pain.

\section{Results}

\section{Sample Description}

Of the 60 adolescents who completed the study, 16 met the criteria for CP and 40 reported NP. Demographic data are presented in Table 1. Two adverse events occurred during the study when adolescents reported a worry that implied danger to themselves or others, which were reported.

\section{Worry identification and categorisation}

There were 675 worry episodes and consequences reported by adolescents in total. The inter-rater reliability for the categories pertaining to worry content and consequences was moderate $\mathrm{K}=.51, p<.01,95 \%$ confidence intervals $(\mathrm{CI})=0.48-0.54 ; \mathrm{K}=.48, p<.01,95 \% \mathrm{CI}=0.45$ 0.51 , respectively. 


\section{Worry characteristics of adolescents}

Characteristics of worry content and consequences are presented in Tables $2 \& 3$ (Note: Tables S1 \& S2 include examples of worry content and consequences). Of the 63 worries related to health, 20 included the word "pain", "hurt" "headache", or implied joint pain.

Adolescents were asked to identify an emotion associated with each worry and report the strength of that emotion. Across all worries, adolescents reported feeling "frustrated" most often. "Terrified" was the strongest emotion $M=7.42(S D=2.04)$ and "silly" was the least strong emotion $M=4.74(S D=2.00)$.

Results of the MANOVAs on CP status on 1) quantity, mean strength, or mean interference of all worry content and 2) quantity and strength of all worry consequences, revealed no significant differences $\mathrm{CP}$ (see Table 4).

\section{Discussion}

We reported the content and characteristics of everyday daily worry experienced by older adolescents in the community. Despite research conducted on the effects of anxiety during childhood and in adolescents with chronic pain, there has been less work investigating naturally occurring worries. This is important to ensure we are assessing relevant anxiety symptoms in practice and research. Our findings supported previous research in younger adolescents who worried predominantly about personal competence, the desire to perform at a socially desirable level in all aspects of life (school, social, and personal life) (Muris, Merckelbach, Meesters, \& van den Brand, 2002; Silverman, Greca, \& Wasserstein, 1995; Vasey et al., 1994; Weems \& Costa, 2005) and adds to previous research showing that intolerance of uncertainty and negative problem orientation are positively associated with higher worry in adolescents (Laugesen et al., 
2003). We were also able to capture novel characteristics of worries, including the emotions evoked by worries and the consequences of their worry content. Adolescents reported that they felt "frustrated" by their worries most often, although individual worries can be severe; "terrified" was the strongest emotional description expressed. Adolescents reported personal competence consequences of their worries, such as fear of being criticized, being judged negatively, or others expressing negative emotions towards them.

An exploratory aim of this study to investigate worries between adolescents with and without chronic pain from the community identified no differences between groups. However, a third of worries reported by all adolescents within the health category were associated with pain, showing that this is a common worry for this age group. Although pain is known to interrupt and dominate cognitive processes (Verhoeven, Dick, Eccleston, Goubert, \& Crombez, 2014) it is possible that adolescents who identified as having chronic pain in this study did not experience the pain as interfering and interruptive, and therefore, their pain was not a prominent source of worry.

A number of limitations should be considered when interpreting the findings. Only a small number of boys were recruited and as such, we were unable to compare sexes in our analyses. Further, only 16 adolescents with chronic pain were recruited which limits our interpretations. Further, it was not possible to check the compliance of adolescents due to the use of paper and pen diary employed. The coding system of categorising worry content and consequence was novel and its validity has not been explored previously in this population. This study was primarily descriptive, meaning further investigation is warranted to understand the clusters of worries identified. Finally, adolescents were drawn from a community sample of 
older adolescents and are not a clinical sample. Future research could be improved by addressing these limitations.

In summary, worry is a common feature of adolescence. Adolescents worry primarily about personal competence such as schoolwork, and about judging their own competence or being judged negatively by others. 


\section{References}

Borkovec, T. D. (1994). The nature, functions and origins of worry. In G. C. L. Davey \& F. Tallis (Eds.), Worrying: Perspectives on Theory, Assessment and Treatment. (pp. 5-33). Chichester: John Wiley and Sons Ltd.

Caes, L., Fisher, E., Clinch, J., Tobias, J., \& Eccleston, C. (2016). The development of worry throughout childhood: Avon Longitudinal Study of Parents and Children data. British Journal of Health Psychology, 21(2), 389-406. doi:10.1111/bjhp.12174

Costello, E. J., Mustillo, S., Erkanli, A., Keeler, G., \& Angold, A. (2003). Prevalence and development of psychiatric disorders in childhood and adolescence. Archives of General Psychiatry, 60(8), 837.

Eccleston, C., \& Crombez, G. (2007). Worry and chronic pain: a misdirected problem solving model. Pain, 132(3), 233-236.

Laugesen, N., Dugas, M. J., \& Bukowski, W. M. (2003). Understanding Adolescent Worry: The Application of a Cognitive Model. Journal of Abnormal Child Psychology, 31(1), 55-64. doi:10.1023/a:1021721332181

McClure, E. B., Brennan, P. A., Hammen, C., \& Le Brocque, R. M. (2001). Parental Anxiety Disorders, Child Anxiety Disorders, and the Perceived Parent-Child Relationship in an Australian High-Risk Sample. Journal of Abnormal Child Psychology, 29(1), 1-10. doi:10.1023/a:1005260311313

Muris, P., Merckelbach, H., Meesters, C., \& van den Brand, K. (2002). Cognitive development and worry in normal children. Cognitive Therapy and Research, 26(6), 775-787. 
Palermo, T. M., Valrie, C. R., \& Karlson, C. W. (2014). Family and parent influences on pediatric chronic pain: a developmental perspective. Am Psychol, 69(2), 142-152. doi:10.1037/a0035216

Perquin, C. W., Hazebroek-Kampschreur, A. A. J. M., Hunfeld, J. A., Bohnen, A. M., van Suijlekom-Smit, L. W. A., Passchier, J., \& van der Wouden, J. C. (2000). Pain in children and adolescents: a common experience. Pain, 87(1), 51-58.

Silverman, W. K., Greca, A. M., \& Wasserstein, S. (1995). What do children worry about? Worries and their relation to anxiety. Child development, 66(3), 671-686.

Simons, L. E., \& Kaczynski, K. J. (2012). The fear avoidance model of chronic pain: examination for pediatric application. The Journal of Pain, 13(9), 827-835.

Simons, L. E., Sieberg, C. B., \& Claar, R. L. (2012). Anxiety and impairment in a large sample of children and adolescents with chronic pain. Pain Research and Management, 17(2), 93-97.

Szabo, M., \& Lovibond, P. F. (2004). The cognitive content of thought-listed worry episodes in clinic-referred anxious and nonreferred children. Journal of Clinical Child and Adolescent Psychology, 33(3), 613-622. doi:10.1207/s15374424jccp3303_18

Vasey, M. W., \& Borkovec, T. D. (1992). A catastrophizing assessment of worrisome thoughts. Cognitive Therapy and Research, 16(5), 505-520.

Vasey, M. W., Crnic, K. A., \& Carter, W. G. (1994). Worry in childhood: A developmental perspective. Cognitive Therapy and Research, 18(6), 529-549.

Verhoeven, K., Dick, B., Eccleston, C., Goubert, L., \& Crombez, G. (2014). The role of executive functioning in children's attentional pain control: An experimental analysis. Pain, 155(2), 413-421. doi:http://dx.doi.org/10.1016/j.pain.2013.11.002 
Von Korff, M., Ormel, J., Keefe, F. J., \& Dworkin, S. F. (1992). Grading the severity of chronic pain. Pain, 50(2), 133-149.

Warwick, H., \& Salkovskis, P. M. (1990). Hypochondriasis. Behaviour research and therapy, 28(2), 105-117.

Weems, C. F., \& Costa, N. M. (2005). Developmental differences in the expression of childhood anxiety symptoms and fears. Journal of the American Academy of Child \& Adolescent Psychiatry, 44(7), 656-663.

Wilson, C., Budd, B., Chernin, R., King, H., Leddy, A., Maclennan, F., \& Mallandain, I. (2011). The role of meta-cognition and parenting in adolescent worry. Journal of Anxiety Disorders, 25(1), 71-79. doi:http://dx.doi.org/10.1016/j.janxdis.2010.08.005

Woodward, L. J., \& Fergusson, D. M. (2001). Life course outcomes of young people with anxiety disorders in adolescence. Journal of the American Academy of Child \& Adolescent Psychiatry, 40(9), 1086-1093. 
Table 1. Demographics table. Individual $n$ s for means and $S D$ are provided in table. Pain characteristics are described using the chronic pain criterion.

\begin{tabular}{|c|c|c|c|}
\hline & $\begin{array}{l}\text { Whole sample } \\
(N=60) M(S D)\end{array}$ & $\begin{array}{l}\text { Chronic pain } \\
\text { adolescents }{ }^{1} \\
(n=16) M(S D)\end{array}$ & $\begin{array}{l}\text { Non chronic pain } \\
\text { adolescents } \\
(n=40) M(S D)\end{array}$ \\
\hline Age $(n=54)$ & $16.83(0.57)$ & $16.53(0.64)$ & $16.97(0.50)$ \\
\hline Sex F:M $M^{2}$ & $46: 13$ & $13: 3$ & $33: 9$ \\
\hline \multicolumn{4}{|l|}{ Ethnicity $N(\%)$} \\
\hline White & $54(90)$ & $15(94)$ & $37(93)$ \\
\hline Black & $1(2)$ & $0(0)$ & $1(2.5)$ \\
\hline Asian & $0(0)$ & $0(0)$ & $0(0)$ \\
\hline Other & $3(5)$ & $1(6)$ & $2(5)$ \\
\hline Missing & $2(3)$ & - & - \\
\hline Medical diagnosis & 10 & 7 & 2 \\
\hline \multirow{2}{*}{$\begin{array}{l}\text { Number of pain sites } \\
\text { on body manikin }\end{array}$} & $n=25$ & $n=15$ & $n=9$ \\
\hline & $4.24(3.15)$ & $5.67(3.31)$ & $2.22(0.97)$ \\
\hline \multirow{2}{*}{$\begin{array}{l}\text { Overall pain from last } \\
\text { week }(0-10)\end{array}$} & $n=25$ & $n=15$ & $n=9$ \\
\hline & $3.70(2.19)$ & $4.53(2.00)$ & $2.28(1.95)$ \\
\hline \multirow{2}{*}{$\begin{array}{l}\text { Current pain level (0- } \\
10)\end{array}$} & $n=27$ & $n=15$ & $n=11$ \\
\hline & $2.04(2.19)$ & $2.20(1.61)$ & $1.81(2.09)$ \\
\hline \multirow{2}{*}{$\begin{array}{l}\text { Number of days } \\
\text { missed from school } \\
\text { (per week) }\end{array}$} & $n=11$ & $n=10$ & $n=1$ \\
\hline & $0.27(0.65)$ & $0.30(0.68)$ & $0.0(0.00)$ \\
\hline
\end{tabular}

${ }^{1}$ Four adolescents did not report whether they had chronic pain or not, hence the whole sample may not total the chronic pain and no pain groups.

${ }^{2}$ One adolescent did not report sex and one male did not report chronic pain status. 
Table 2. Characteristics of all worry content and consequences

\begin{tabular}{lll}
\hline Variable & $\boldsymbol{M}(\boldsymbol{S D})$ & Range \\
\hline Quantity of worry content (Median, IQR) & $9.0(6.25-15.50)$ & $0-34$ \\
Strength of worry content & $6.61(1.27)$ & $0-10$ \\
Inference of worry content & $4.14(1.61)$ & $0-10$ \\
Quantity of consequences (Median, IQR) & $9.0(7.00-15.00)$ & $0-41$ \\
Strength of consequences & $5.59(1.41)$ & $0-10$ \\
\hline
\end{tabular}

$M=$ mean; $S D=$ standard deviation; $\mathrm{IQR}=$ Interquartile range. 
Table 3. Characteristics of worry content and consequences reported by categories $31(4.6 \%)$ worry content and $44(6.5 \%)$ worry consequences could not be assigned a category.

\begin{tabular}{|c|c|c|c|c|c|c|}
\hline \multirow[b]{2}{*}{ Category of worry } & \multirow{2}{*}{$\begin{array}{l}N \text { worry } \\
\text { content }\end{array}$} & \multirow[b]{2}{*}{ 1st } & \multicolumn{2}{|c|}{ Modal feeling of worry content } & \multirow[b]{2}{*}{$4^{\text {th }}$} & \multirow{2}{*}{$\begin{array}{c}N \text { worry } \\
\text { consequences }\end{array}$} \\
\hline & & & 2nd & 3rd & & \\
\hline Health & 63 & $\begin{array}{l}\text { Frustrated }(n= \\
20)\end{array}$ & Scared $(n=11)$ & Helpless $(n=6)$ & $\begin{array}{l}\text { Hopeless; } \\
\text { Overwhelmed } \\
(n=4)\end{array}$ & 69 \\
\hline Relationships & 41 & $\begin{array}{l}\text { Guilty; Sad ( } n= \\
\text { 8) }\end{array}$ & $\begin{array}{l}\text { Frustrated; } \\
\text { Confused }(n= \\
\text { 5) }\end{array}$ & Scared $(n=4)$ & Helpless $(n=3)$ & 31 \\
\hline Personal competence & 405 & $\begin{array}{l}\text { Frustrated }(n= \\
71)\end{array}$ & Scared $(n=52)$ & $\begin{array}{l}\text { Ashamed }(n= \\
37)\end{array}$ & Silly $(n=32)$ & 369 \\
\hline Other & 135 & Scared $(n=29)$ & $\begin{array}{l}\text { Helpless }(n= \\
24)\end{array}$ & $\begin{array}{l}\text { Frustrated ( } n= \\
19)\end{array}$ & $\operatorname{Sad}(n=18)$ & 164 \\
\hline
\end{tabular}


Table 4. MANOVA investigating differences between worry characteristics and CP status

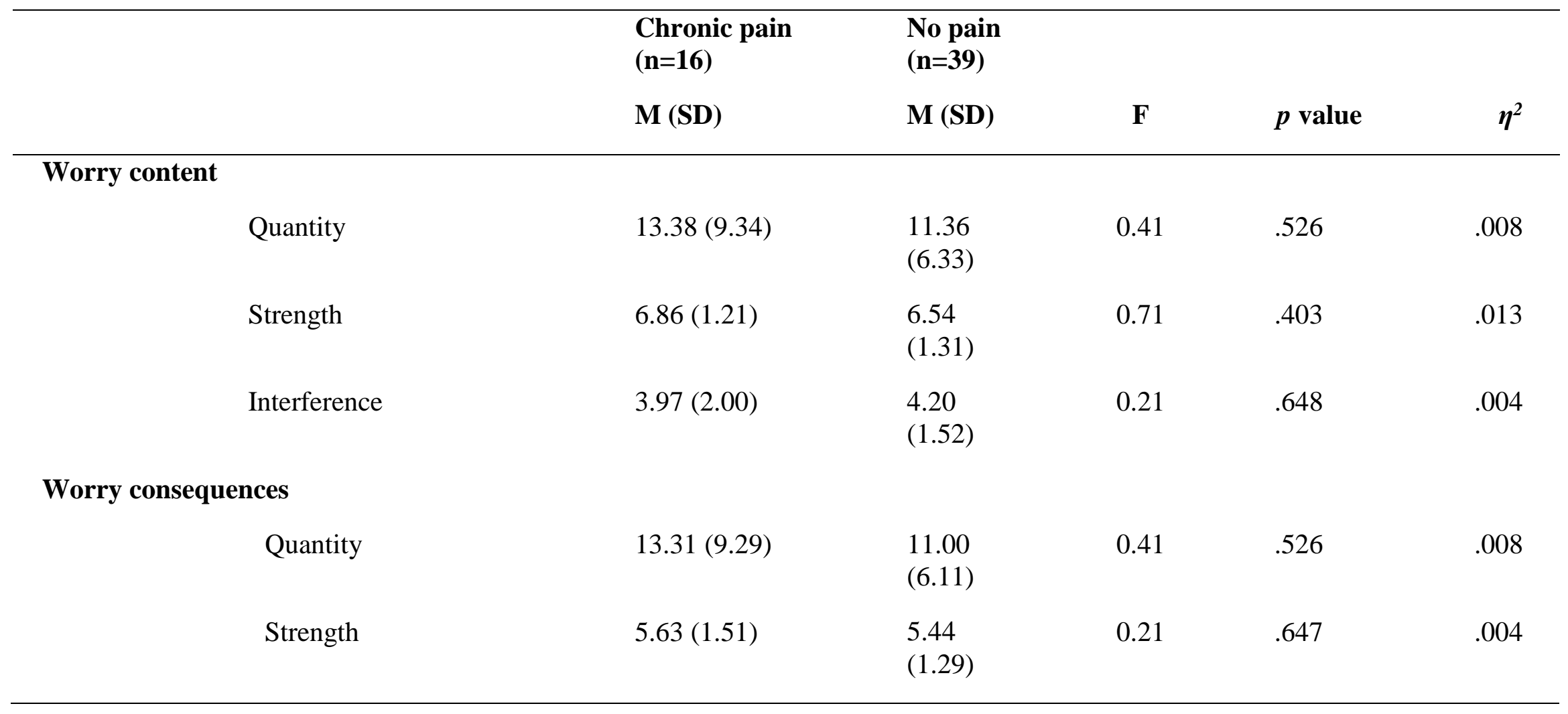


Table S1. Examples of worries categorised by worry category

\begin{tabular}{|c|c|c|}
\hline Category & Worry content & Worry consequence \\
\hline Health & $\begin{array}{l}\text { "Is the cut on my lip going to turn into a cold sore?" } \\
\text { "My tooth is hurting" } \\
\text { "I will never change, considering my worrying } \\
\text { constantly" } \\
\text { "That I will get more serious mental illnesses as I get } \\
\text { older" }\end{array}$ & $\begin{array}{l}\text { "I'd end up with a horrible cold sore and people will } \\
\text { judge me" } \\
\text { "I would need a filling" } \\
\text { "Lead a stressful, sad life" } \\
\text { "I could get help/prevent it from occurring" }\end{array}$ \\
\hline Relationships & $\begin{array}{l}\text { "I will lose touch with friends" } \\
\text { "That I don't fit in with my school friends" } \\
\text { "My friends are going to fall out" } \\
\text { "Boyfriend isn't talking to me. Not sure if it's something } \\
\text { I've said or done but every event of today is flooding } \\
\text { back with negative points about things" }\end{array}$ & $\begin{array}{l}\text { "I will never see them again" } \\
\text { "They may end up thinking badly of me or leave me out" } \\
\text { "Drama. Divide in the friendship group" } \\
\text { "I don't know how this could really come true! Maybe an } \\
\text { argument if it was something I'd done?" }\end{array}$ \\
\hline $\begin{array}{c}\text { Personal } \\
\text { competence }\end{array}$ & $\begin{array}{l}\text { "Failing exams", } \\
\text { "That my results won't be good enough" } \\
\text { "That I won't get into the university I want" } \\
\text { "I will have lots of spots" } \\
\text { "I am getting a full fringe put in next week and I don't } \\
\text { know if it will suit me" }\end{array}$ & $\begin{array}{l}\text { "I wouldn't go to the university want to" } \\
\text { "People would be disappointed and I wouldn't get into } \\
\text { Uni" } \\
\text { "I would be at home for the rest of my life" } \\
\text { "I would feel self-conscious" } \\
\text { "I will regret it" }\end{array}$ \\
\hline Other & $\begin{array}{l}\text { "That my car seat won't be able to be fixed so I'll have } \\
\text { to pay for someone to fix it" } \\
\text { "The world being so tiny in a huge black space" } \\
\text { "I don't know what career path to choose and fear I'll } \\
\text { end up getting sucked into a job I don't like" }\end{array}$ & $\begin{array}{l}\text { "I would run out of money and wouldn't be able to buy } \\
\text { other things I need" } \\
\text { "is" } \\
\text { "I'd lead a miserable life" }\end{array}$ \\
\hline Uncategorised & $\begin{array}{l}\text { "I'm worried my brother's girlfriend will shout about me } \\
\text { or to me because I accidently ate food that was hers in } \\
\text { our fridge" } \\
\text { "Two good friends have sadly ended their relationship, } \\
\text { probably end up counselling and consoling" }\end{array}$ & $\begin{array}{l}\text { "It would upset me a lot and make me feel unwanted in } \\
\text { my own house" } \\
\text { "Phone calls, kind words and hopefully those two will } \\
\text { become a couple again" }\end{array}$ \\
\hline
\end{tabular}


Table S2. Examples of worries categorised by worry consequence

\begin{tabular}{|c|c|c|}
\hline Category & Worry content & Worry consequence \\
\hline Health & $\begin{array}{l}\text { "My tooth is hurting" } \\
\text { "The hotel we are going to stay in overnight is going to be } \\
\text { unclean" } \\
\text { "That I will get more serious mental illnesses as I get older" }\end{array}$ & $\begin{array}{l}\text { "I would need a filling" } \\
\text { "I will be covered in germs" } \\
\text { "I could get help/prevent it from occurring" }\end{array}$ \\
\hline Relationships & $\begin{array}{l}\text { "I will lose touch with friends" } \\
\text { "My friends are going to fall out" } \\
\text { "I'm worried my brother's girlfriend will shout about me or } \\
\text { to me because I accidently ate food that was hers in our } \\
\text { fridge" } \\
\text { "My sisters are turning into people I don't like as much" }\end{array}$ & $\begin{array}{l}\text { "I will never see them again" } \\
\text { "Drama. Divide in the friendship group" } \\
\text { "It would upset me a lot and make me feel unwanted in my } \\
\text { own house" } \\
\text { "We will continue to argue lots, I will get stressed, and our } \\
\text { relationship will get damaged for the future" }\end{array}$ \\
\hline $\begin{array}{c}\text { Personal } \\
\text { competence }\end{array}$ & $\begin{array}{l}\text { "That my results won't be good enough" } \\
\text { "Is the cut on my lip going to turn into a cold sore?" } \\
\text { "That I don't fit in with my school friends" } \\
\text { "People think I'm ugly and too masculine" }\end{array}$ & $\begin{array}{l}\text { "People would be disappointed and I wouldn't get into Uni" } \\
\text { "I'd end up with a horrible cold sore and people will judge } \\
\text { me" } \\
\text { "They may end up thinking badly of me or leave me out" } \\
\text { "Feel absolutely rubbish, more self-conscious and odd" }\end{array}$ \\
\hline Other & $\begin{array}{l}\text { "That my car seat won't be able to be fixed so I'll have to pay } \\
\text { for someone to fix it" } \\
\text { "Two good friends have sadly ended their relationship, } \\
\text { probably end up counselling and consoling" } \\
\text { "That I won't get into the university I want" }\end{array}$ & $\begin{array}{l}\text { "I would run out of money and wouldn't be able to buy other } \\
\text { things I need" } \\
\text { "Phone calls, kind words and hopefully those two will } \\
\text { become a couple again" } \\
\text { "I would be at home for the rest of my life" }\end{array}$ \\
\hline Uncategorised & $\begin{array}{l}\text { "My subjects I'm taking aren't enough for me to stand out in } \\
\text { University application" } \\
\text { "I am getting a full fringe put in next week and I don't know } \\
\text { if it will suit me" }\end{array}$ & $\begin{array}{l}\text { "Be upset, disappointed and frustrated" } \\
\text { "I will regret it" }\end{array}$ \\
\hline
\end{tabular}

